\title{
小児患者とICU-acquired weakness
}

ICU-acquired weakness (ICU-AW) の存在は, 集中 治療医の間で広く認識されている。2014年のKress らの総説 ${ }^{11}$ は, その存在と概念を解説している代表的 なものである。しかし, 小児領域では, この概念は認 識されてはいるものの，実態はわかっていない。「そ の頻度は？」「どうやって診断するのか？」「関連因子 は何なのか?」といったことが明確になっていない。 そういった観点からは, 本誌本号に掲載の熊丸ら2)の 小児のICU-AWに関する論文は, 世界的に見ても重要 な研究である。

成人でのICU-AW は, 敗血症, 多臟器障害, あるい は長期人工呼吸の患者において, $46 \%$ という高頻度で 発生していると報告されて扔り3), 重症の病態での頻 度が高いことが指摘される。一方で, 小児のICU-AW に関する報告は極めて少ない 4) 6)。ICU-A W の発生 頻度は, 米国の大規模な PICUデータベースでの研究4) では $0.02 \%$, カナダの単一施設から ${ }^{5)} 1.7 \%$ という数 字が報告されている。ICU-AW そのものの診断の難し さはあるにせよ, これらの数字は, 小児集中治療に従 事している者にとっては過小評価されているのではな いかと感じる。一方, インドでの7日以上人工呼吸管 理を必要とする小児患者では, 32 人中 29 人で, polyneuropathy (ICU-AWの一つ) が存在したという 報告6)もある。本号の熊丸ら 2) は, 先天性心疾患術後 の患者を対象に行った研究で, ICU-AWの頻度は 25.5\%であった。

なぜこのように, 報告によって頻度が異なるのであ ろうか。その一つは, 研究ごとにICU-AW の診断が異 なるからである。成人でのICU-AWの診断では, de Jongheらの方法7) (Medical Research Council score, MRC score) が用いられることが一般的である。熊丸 らは, この方法 (一部変法)を用いている。一方で, MRC scoreでの評価は, 小児でICU-AWを診断する 上では評価者ごとのばらつきがあり，あまり適してい ないと指摘する研究8ももる。熊丸らの報告では, その 評価は単一の理学療法士が行っているため, 他の評価者 が行った場合の再現性を追求できない。前述した他の 研究では, データベース研究4)に打いて, International Classification of Disease, Ninth Revision (ICD-9) での neuropathy myopathyに関連する診断名を用いて ICU-AW と思われる症例を抽出しており, カナダから の報告5)では, MRC scoreでスクリーニング(単一筋 で4点以下でのスクリーニングの後)を行ってはいる ものの, 最終的には小坚神経科医の診察の後に決定し ている。インドからの報告6) は, neuropathyに焦点を 当てているために, MRC scoreでスクリーニングを 行った後に, 神経伝達速度検査で診断している。熊丸 らは, ICU 経過の比較的早期〔筋弛緩薬使用患者では, 筋弛緩中止後1日 (中央值) 〕でMRC scoreを評価して いるが, この早い夕イミングによって比較的多くの患 者がICU-AW と診断されている側面もあるかもしれ ない。同一の患者が, その1週間後に筋力がどうなっ ているかも知りたいところである。

小児のICU-AWに関連する因子としては, 原疾患や 病態としては, 呼吸器疾患・感染症診断4), 多臟器 不全5)や敗血症5),6), 治療に関わる因子としては, 腎代 替療法・extracorporeal membrane oxygenation $(\mathrm{ECMO})$ 治療・人工呼吸 ${ }^{4)}$, ステロイド薬・筋弛緩 薬・アミノグリコシド系抗菌薬5が挙げられている。 熊丸らは, 先天性心疾患手術の難易度や筋驰緩薬使用 とその期間が ICU-AW と関係があるとしている。こ れらの報告から, 小児においても, ICU入室を必要と する患者の重症度や, その治療に扔ける筋驰緩薬の使 用などがICU-AW と関連していると推察できる。

さて, 先天性心疾患の術後の成績に目を転じてみよ う。これらの手術成績は, 主に生存率に焦点が当てら れることが多い。しかし, 先天性心疾患の術後管理に 従事している者にとっては, 生死のみがアウトカムで はなく, 様々な合併症の評価も重要である。英国の代 表的な小児医療施設から, 人工心肺を用いた手術後の ICUの長期滞在におけるリスク因子の報告がある9)。 この報告では, 長期 ICU 滞在のリスク因子として, 新 生児, 術前の人工呼吸管理, 手術の難易度などを挙げ ている。この中では, 手術の難易度が熊丸らの報告と 共通している。この英国の研究は, 単にICU滞在日数 に焦点を当てているだけであり, muscle weaknessに 注目したものではない。したがって, 筋弛緩薬やステ ロイド薬の使用に関しての言及はない。ただし,一般 
に新生児期に手術が必要な先天性心疾患は, 単心室形 態の病態を多く含み, 手術の難易度は高い。その結果 として, 術後は筋弛緩薬やステロイド薬を使用するこ とが多い。

小児のICU-AWに対する効果的な介入に関しては， 未知である。早期の理学療法の導入に期待が寄せられ, PICUでも早期理学療法が導入されている。その効果 に関する報告 10),11) は, 現時点では限定的である。本号 の熊丸らの研究をきっかけに, 日本においても小児の ICU-AWがもっと注目され, この方面での研究が進む ことが期待される。また，世界的に見ても小児領域の この分野は未開であり, 日本から海外へ向けての情報 発信も重要である。

本稿の著者に規定されたCOIはない。

\section{文 献}

1) Kress JP, Hall JB. ICU-acquired weakness and recovery from critical illness. N Engl J Med 2014;370:1626-35.

2) 熊丸めぐみ, 下山伸哉, 岡 徳彦, 他. 小児先天性心疾患 手術後患者におけるICU-acquired weaknessの発症状況と そのリスク因子．日集中医誌 2020;27:267-72.

3) Stevens RD, Dowdy DW, Michaels RK, et al. Neuromuscular dysfunction acquired in critical illness: a systematic review. Intensive Care Med 2007;33:1876-91.

4) Field-Ridley A, Dharmar M, Steinhorn D, et al. ICU-acquired weakness is associated with differences in clinical outcomes in critically ill children. Pediatr Crit Care Med 2016;17:53-7.

5) Banwell BL, Mildner RJ, Hassall AC, et al. Muscle weakness in critically ill children. Neurology 2003;61: 1779-82.

6) Shubham S, Dhochak N, Singh A, et al. Polyneuropathy in critically ill mechanically ventilated children: experience from a tertiary care hospital in North India.
Pediatr Crit Care Med 2019;20:826-31.

7) de Jonghe B, Sharshar T, Lefaucheur JP, et al; Groupe de Réflexion et d'Etude des Neuromyopathies en Réanimation. Paresis acquired in the intensive care unit: a prospective multicenter study. JAMA 2002;288:2859-67.

8) Siu K, Al-Harbi S, Clark H, et al. Feasibility and reliability of muscle strength testing in critically ill children. J Pediatr Intensive Care 2015;4:218-24.

9) Brown KL, Ridout DA, Goldman AP, et al. Risk factors for long intensive care unit stay after cardiopulmonary bypass in children. Crit Care Med 2003;31:28-33.

10) Tsuboi N, Nozaki H, Ishida $Y$, et al. Early mobilization after pediatric liver transplantation. J Pediatr Intensive Care 2017;6:199-205.

11) Tsuboi N, Hiratsuka M, Kaneko S, et al. Benefits of early mobilization after pediatric liver transplantation. Pediatr Crit Care Med 2019;20:e91-7.

受付日 2020 年 3 月 13 日 採択日 2020 年 3 月 19 日

$$
\begin{aligned}
& \text { 中川 聡 } \\
& \text { 国立成育医療研究センター手術・集中治療部 } \\
& (\text { ～} 157-8535 \text { 東京都世田谷区大蔵2-10-1) }
\end{aligned}
$$

\section{ICU-acquired weakness in Children}

Key words: (1) ICU-acquired weakness (ICU-AW), (2) child, (3) diagnosis

Satoshi Nakagawa

Department of Critical Care and Anesthesia, National Center for Child Health and Development

(2-10-1 Okura, Setagaya-ku, Tokyo 157-8535, Japan)

J Jpn Soc Intensive Care Med 2020;27:259-60. 